\title{
CORRESPONDENCE
}

\section{THE FACULTY OF OPHTHALMOLOGISTS}

To the Editors of THE BRITISH JOURNAL OF OPHTHALMOLOGY.

DEAR SIRS, - The formation of the Faculty of Ophthalmologists appears to me to come at an inopportune time. To increase the number of organisations to watch over ophthalmologists' interests is to invite division of effort and confusion of thought.

I do not like the Faculty's proposal to have two kinds of members. We want to encourage the younger men, and the suggestion that only six members of Council are to be elected by the Associate members, that is, those of two to five years standing, and others of more seniority, who are not on the staff of a Hospital of arbitrary size, while the older members elect fifteen, is undesirable.

How can the Faculty be fully representative if it excludes the part-time ophthalmologist, whose numbers are indeed, far higher than those of the full-time practitioner? It is from these "parttimers" that we must expect much help in the proposed National Health Service, for without them we shall be unable to put forward a scheme for a medical examination for every patient, for which the Government has expressed a desire.

"United we stand, divided we fall." The ophthalmic group of the B.M.A. is surely best constituted to be the guardian angel. It is democratically elected and all electors of equal status, whether practising ophthalmology wholly or predominantly, and is, therefore, fully representative. Let all ophthalmologists rally round the B.M.A., attend the regional meetings and put their views and desires before their representative on the ophthalmic group committee. By so doing, we present a united front to the Minister of Health when the time comes.

$$
\begin{aligned}
& \text { Yours faithfully, } \\
& \text { C. R. DunCAN LeEds. }
\end{aligned}
$$

EDINBURGH

February 19, 1945.

To the Editors of THE BRITISH JOURNAL OF OPHTHALMOLOGY.

SIR,-Ophthalmologists are agreed as to the need for a united body to represent the profession in all its aspects. At present, three bodies, the Ophthalmic Group Committee of the B.M.A., the Council of British Ophthalmologists and the Association of British Ophthalmologists all profess to be interested in medico-political affairs. It was hoped that the recent negotiations between representatives of the C.B.O. and the A.B.O. would produce the desired body, and general regret will be felt at the apparent failure. 
- The A.B.O. has not yet decided on its attitude to the proposed Faculty published by the C.B.O., but as a member of its negotiating committee I cannot but fear that this proposed Faculty, instead of uniting the profession and producing the desired united body, will intensify distrust and make more difficult that unity which is so essential today. The circumstances in which this Faculty has been registered, the obvious lack of consideration of detail and the haste with which it has been foisted on the profession give rise to much uneasiness.

Of the many additional objections which will be raised, threemay be mentioned. (1) A Faculty is not the proper body to deal with medico-political affairs. A Faculty is generally regarded as an academic body, as witness the recent Faculties of Radiology and Homoeopathy. (2) The proposed Faculty makes no provision - for part-time Ophthalmologists. The united body that is required should not only deal with Ophthalmology in all its aspects, but should cater for every section of the profession. (3) The democratic character of the proposed Faculty is in doubt. "The Council shall call an annual general meeting of the Faculty to receive and discuss its report," p. 108. Alongside this it is only fair to place a recent decision of the C.B.O., namely, "Decisions or recommendations of ány maş meeting of members or associates should be considered by the Council but should not necessarily be acted upon nor implemented."

These difficulties are not insurmoutable, and I do nót despair of the formation of a body acceptable to all parties. To secure this, and I write to suggest that another effort be made by calling together representatives, say, four in number, from each of the three bodies, the O.G.C., the C.B.O., and the A.B.O., and that under an independent Chairman they tackle the problem afresh. Meantime the present proposals for a Faculty should be held in abeyance.

\section{Yours faithfully,}

J. N. TENNENT.

GLASGOW,

February 17, 1945.

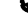

\section{DARK ADAPTATION IN DETECTING VITAMIN 'A' DEFICIENCY}

To the Editors of THE BRITISH JOURNAL OF OPHTHALMOLOGY.

Dear Sirs,-I risk these comments on "Studies in dark adaptation as a means of detecting deficiency of Vitamin "A'" published in your Journal of November, 1944, being mistakenly provocative because the matter is so obviously important to the 